\title{
EFEKTIVITAS KEPEKATAN LARUTAN SODIUM HYPOCHLORITE TERHADAP BIAKAN KUMAN STAPHYLOCOCCUS AUREUS
}

\author{
Fajar Ivan Effendi ${ }^{1}$, Rieva ermawan $^{2}$, Pamudji Utomo ${ }^{3}$,Ismail Maryanto ${ }^{3}$, Asep Santoso ${ }^{3}$ \\ ${ }^{1}$ Fakultas Kedokteran Universitas Sebelas Maret, \\ ${ }^{2} R S U D$ Dr. Moewardi Surakarta \\ ${ }^{3} R S$ Orthopaedi dr. Soeharso Surakarta. \\ Email :fajareffendiortho@yahoo.com
}

\begin{abstract}
Background: Musculoskeletal infections have complex complications, making them a challenge. Most countries have experienced Staphylococcus aureus resistance to methicillin by $25 \%$ and some even over $50 \%$. Dakin solution $(0.050 \%$ to $0.025 \%)$ can be used as irrigation, cleansing, and used on moist gauze for the management or prevention of skin or tissue infections. This study aims to determine the lowest concentration level of Dakin solution / sodium hypochlorite which is the safest and most effective in the culture of Staphilococcus aureus.

Methods: This research is an analytical experimental research, with the concept of comparing the Staphylococcus aureus ATCC 25923 germ cultures which are treated in the form of giving dakin solution / sodium hypochlorite $0.050 \%, 0.025 \%, 0.0125 \%$ and control using $0.9 \% \mathrm{NaCl}$. Observation of the effectiveness is done by measuring the formed inhibition zone.

Result and Conclusion: The concentration of $0.025 \%$ gives a fairly good disinfectant effect with moderate inhibition power, the concentration of $0.050 \%$ gives a good disinfectant effect with a strong inhibitory power while the concentration of $0.0125 \%$ does not have a disinfectant effect, this is the same as the $0.9 \% \mathrm{NaCl}$ control solution. The zone of inhibition in the staphylococcus aureus bacteria culture ATCC 25923 at concentrations of $0.025 \%$ and $0.050 \%$ still gave a stable effect until evaluation within $2 \times 24$ hours (48 hours).
\end{abstract}

Keywords : Dakin solution, Sodium hypoclorite, resistor zone, Staphylococcus aureus

\section{ABSTRAK}

Pendahuluan: Infeksi musculoskeletal memiliki komplikasi yang rumit, sehingga menjadi tantangan. Sebagian besar negara telah mengalami resistensi Staphylococcus aureus terhadap methicillin sebesar $25 \%$ dan bahkan beberapa di atas 50\%. Dakin solution (0.050\% hingga 0.025\%) dapat digunakan sebagai irigasi, pembersih, dan digunakan pada kassa lembab untuk penatalaksanaan atau pencegahan pada kulit atau infeksi pada jaringan. Penelitian ini bertujuan untuk Mengetahui tingkat kepekatan terendah Dakin solution/sodium hypochlorite yang paling aman dan efektif pada biakan kuman Staphilococcus aureus.

Metode: Penelitian ini merupakan Penelitian Eksperimental analitik, dengan konsep membandingkan antara biakan kuman Staphilococcus aureus ATCC 25923 yang dilakukan perlakuan berupa pemberian dakin solution/sodium hypochlorite 0,050\%, 0,025\%, 0,0125\% dan kontrol menggunakan $\mathrm{NaCl}$ 0,9\%. Pengamatan efektifitas dilakukan dengan cara mengukur zona hambat yang terbentuk.

Hasil dan Kesimpulan: Kepekatan 0,025\% memberikan efek desinfektan yang cukup baik dengan daya hambat sedang, kepekatan 0,050\% memberikan efek desinfektan yang baik dengan daya hambat kuat sedangkan kepekatan 0,0125\% tidak memberikan efek desinfektan, hal ini sama dengan larutan kontrol $\mathrm{NaCl} \mathrm{0,9 \% .} \mathrm{Zona}$ hambat pada biakan kuman staphylococcus aureus ATCC 25923 pada kepekatan 0,025\% dan 0,050\% tetap memberikan efek yang stabil hingga evaluasi dalam rentang waktu 2x24 jam (48 jam).

Kata Kunci : Dakin solution, Sodium hypoclorite, Zona hambat, Staphylococcus aureus. 


\section{PENDAHULUAN}

Pada bidang orthopaedi, infeksi musculoskeletal memiliki komplikasi yang rumit, sehingga menjadi tantangan. Potensi untuk terjadinya keterlambatan dalam mendiagnosis dan melakukan terapi tetap ada walaupun perkembangan alat terbaru untuk diagnosis dan inovasi terapi selalu berkembang, resistensi bakteri juga menjadi tantangan tersendiri bagi klinisi. ${ }^{1}$

Ketersediaan antibiotika yang semakin meluas dan penggunaan antibiotika yang irasional menimbulkan suatu fenomena resistensi bakteri, salah satunya Staphylococcus aureus. Prevalensi global menunjukkan sebagian besar negara telah mengalami resistensi Staphylococcus aureus terhadap methicillin sebesar $25 \%$ dan bahkan beberapa di atas $50 \%{ }^{2}$

Resistensi dapat terjadi sebagai akibat dari mekanisme pertahanan bakteri terhadap antibiotika.Staphylococcus aureus beradaptasi dengan mengubah gen yang menyandi penicillin-binding protein, tempat berikatan molekul penicillin pada dinding bakteri sehingga timbul strain staphylococcus yang baru, yaitu methicillin-resistant Staphylococcus aureus (MRSA). Sejauh ini, Staphylococcus aureus telah mengalami resistensi terhadap penicillin golongan beta laktam, fluoroquinolone, aminoglycoside, methicillin dan oxacillin. ${ }^{3}$

Resistensi S. aureus terhadap antimikroba yang bekerja selektif membuktikan bahwa adanya adaptasi dari mikroba terhadap antimikroba tersebut. Sejak ditemukannya Penicillin hingga sekarang, didapati resistensi sebesar $90 \%$ dikarenakan mikroba memproduksi enzim B-laktamase yang bekerja menghancurkan cincin B-laktam. Resistensi merupakan masalah yang sering dihadapi dalam terapi penyakit infeksi tulang, sendi. ${ }^{4}$

Ahli kimia inggris Henry Dakin dan Ahli bedah Perancis Alexis Carrel mengenalkan Dakin solution untuk membersihkan dan menggunakan sebagai irigasi pada luka. Hal ini telah digunakan sebagai antiseptik pada luka saat perang dunia I. Mereka menggunakan cairan Carrel-Dakin untuk irigasi luka setelah operasi debridemnt. Hasilnya, Dakin solution menyelamatkan banyak nyawa sejak dikenalkan. ${ }^{5}$

Dikarenakan Biaya yang murah dan efektivitasnya membuat antiseptik bakterisida ini sangat populer di bidang perawatan kesehatan. Cairan ini digunakan untuk treatment atau mencegah infeksi pada luka sayat, abrasi, laserasi, ulkus, stage I-IV pressure ulcer, luka bakar derajat 1 dan 2 dan bahkan digunakan pada saat proses tindakan operasi. ${ }^{6}$

\section{METODE}

Penelitian ini merupakan Penelitian Eksperimental analitik, dengan konsep membandingkan antara biakan kuman Staphilococcus aureus ATCC 25923 yang dilakukan perlakuan berupa pemberian cairan Dakin solution/sodium hypochlorite dengan kepekatan 0,050\%, 0,025\%, 0,0125\% dan kontrol dengan menggunakan Normal saline ( $\mathrm{NaCl}$ 0,9\%). Pengamatan efektifitas dilakukan dengan cara mengukur zona bening yang terbentuk menggunakan alat ukur, yang disebut dengan zona hambat.

\section{HASIL DAN PEMBAHASAN}

1. Tingkat kepekatan Dakin solution/sodium hypochlorite $0,025 \%$ memberikan efek desinfektan yang cukup baik dengan didapatkannya daya 
hambat sedang berdasarkan dari evaluasi zona hambat.

2. Tingkat kepekatan Dakin solution/sodium hypochlorite $0,050 \%$ memberikan efek desinfektan yang baik dengan didapatkannya daya hambat kuat berdasarkan dari evaluasi zona hambat.

3. Pada tingkat kepekatan Dakin solution/sodium hypochlorite 0,0125\% menunjukkan tidak memberikan efek desinfektan, ditandai dengan tidak terdapatnya zona hambat, hal ini sama dengan pada larutan control normal saline $\mathrm{NaCl}$ 0,9\%.

4. Perlakuan pada biakan kuman staphylococcus aureus ATCC 25923 pada kepekatan Dakin solution/sodium hypochlorite $0,025 \%$ dan $0,050 \%$ tetap memberikan efek desinfektan yang stabil hingga evaluasi dalam rentang waktu 2x24 jam (48 jam).

Tabel 1. Perbedaan Biakan Kuman Antara Larutan Dakin 0,050\%, Larutan Dakin 0,025\% Larutan Dakin 0,0125\%, Normal Saline ( $\mathrm{NaCl}$ 0,9\%)

\begin{tabular}{lccc}
\hline $\begin{array}{l}\text { Konsentrasi Sampel Sodium } \\
\text { Hypochlorite }\end{array}$ & Inkubasi 24 jam $(\mathrm{mm})$ & $\begin{array}{c}\text { Inkubasi 48 jam } \\
(\mathrm{mm})\end{array}$ & -value $^{b}$ \\
\hline $0,050 \%$ & $12,47 \pm 0.07$ & $12,47 \pm 0.07$ & 1,000 \\
$0,025 \%$ & $9,60 \pm 0.12$ & $9,60 \pm 0.12$ & 1,000 \\
$0,0125 \%$ & $0.00 \pm 0.00$ & $0.00 \pm 0.00$ & 1,000 \\
Kontrol (NaCl 0,9\%) $^{\text {p-value }}$ & $0.00 \pm 0.00$ & $0.00 \pm 0.00$ & 1,000 \\
\hline
\end{tabular}

Ketarangan : ${ }^{2}$ Uji Kruskal Wallis; ${ }^{b} U j i$ Wilcoxon Rank Test ; * signifikan pada $\alpha=5 \%$

Inkubasi 24 jam dan Inkubasi 48 jam diketahui bahwa hasil uji statistik mendapatkan nilai $p=<0,001$ yang berarti bahwa terdapat perbedaan yang signifikan perbedaan biakan kuman antara Larutan Dakin 0,050\%, Larutan Dakin 0,025\%, Larutan Dakin 0,0125\%, Normal Saline $(\mathrm{NaCl}$ 0,9\%). Dengan demikian dilanjutkan uji post hoc dengan uji Mann whitney untuk mengetahui tingkat signifikansi perbedaan biakan kuman antara kelompok perlakuan secara parsial.

Berdasarkan tabel 2 diketahui bahwa terdapat perbedaan yang signifikan biakan kuman pada waktu Inkubasi 24 jam dan Inkubasi 48 jam dimana Larutan Dakin 0,050\% vs Larutan Dakin 0,025\% ( $p=0,009)$, Larutan Dakin 0,050\%, vs Larutan Dakin 0,0125\% ( $p=0,005$ ), Larutan Dakin $0,050 \%$ vs $\mathrm{NaCl} 0,9 \%$ $(\mathrm{p}=0,005)$, Larutan Dakin $0,025 \%$, vs Larutan Dakin $0,0125 \% \quad(p=0,005)$, Larutan Dakin $0,025 \%$ vs $\mathrm{NaCl} 0,9 \%(\mathrm{p}=0,005)$ mendapatkan hasil yang berbeda signifikan $(p<0,05)$. Sedangkan pada kelompok Larutan Dakin $0,0125 \%$ vs $\mathrm{NaCl} \quad 0,9 \% \quad(\mathrm{p}=1,000)$, tidak menunjukan perbedaan yang signifikan atau memiliki hasil yang sama $(p>0,05)$. 
Tabel 2. Uji Post Hoc (Mann Whitney)

\begin{tabular}{lccc}
\hline \multirow{2}{*}{ Kelompok } & \multicolumn{3}{c}{ p-value } \\
\cline { 2 - 4 } & $0,025 \%$ & $0,0125 \%$ & $\begin{array}{c}\text { Kontrol (NaCl } \\
0,9 \%)\end{array}$ \\
\hline Inkubasi 24 jam & $0.009^{*}$ & $0.005^{*}$ & $0.005^{*}$ \\
$0,050 \%$ & & $0.005^{*}$ & $0.005^{\star}$ \\
$0,025 \%$ & & 1,000 \\
$0,0125 \%$ & & & \\
\hline Inkubasi 48 jam & & $0.005^{*}$ & $0.005^{\star}$ \\
$0,050 \%$ & $0.009^{*}$ & $0.005^{*}$ & $0.005^{\star}$ \\
$0,025 \%$ & & & 1,000 \\
$0,0125 \%$ & & & \\
\hline
\end{tabular}

Ketarangan : Uji Mann Whitney; * signifikan pada $\alpha=5 \%$

\section{KESIMPULAN}

Kepekatan 0,025\% dan 0,050\% memberikan

efek desinfektan pada biakan kuman

Staphylococcus aures ATCC 25923, dan masih sangat efektif dan stabil hingga 2x24 jam (48 jam).

\section{REFERENCES}

1. Gristina AG. 1989. Microbial Adhesion and Pathogenesis of Biomaterial Infections. Orthopaedic Infection Diagnosis and treatment. Saunders Company, USA. 2 : 3-17

2. Wertheim HF, Verbrugh HA. Global Prevalence of Methicillin-Resistant Staphylococcus aureus. The Lancet. 2006;358:1866.

3. The Center for Food Security and Public Health. Methicillin-resistant Staphylococcus aureus. lowa State University. Last Updated: January 2011. Akses: 2 November 2012. [http://www.cfsph.iastate.edu/Factsheets/pdfs/mrsa.pdf].

4. Meani C.. Infection Local Treatment in Orthopaedic Surgery. Bacterial Strategies and Implant Colonization. Springer, New York, 2007.

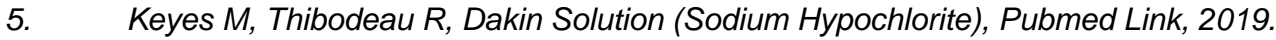

6. McCullough M,Carlson GW, Dakin's solution: historical perspective and current practice., , Annals of plastic surgery, 2014 Sep [PubMed PMID: 25121415]

7. Al-Waili et al. 2011. Honey for Wound Healing, Ulcers, and Burns. The Scientific World Journal 11, 766787.

8. Kerstein MD : The scientific Basis of healing. Adv wound care 1997;10(3):30-36.

9. Axel Kramer et all, Consensus on Wound Antisepsis: Update 2018 Skin Pharmacology Physiology 2018;31:28-58 DOI: 10.1159/000481545.

10. Wilson JW et al. 2002. Mechanism of Bacterial Pathogenicity. Postgraduate Medical Journal 78: 216224

11. Murray PR. Bacterial Pathogenicity. Medical Microbiology, 5th ed. Elsevier.

12. Gristina AG. 1989. Microbial Adhesion and Pathogenesis of Biomaterial Infections. Orthopaedic Infection Diagnosis and treatment. Saunders Company, USA. 2 : 3-17.

13. Wilson JW et al. 2002. Mechanism of Bacterial Pathogenicity. Postgraduate Medical Journal 78: 216224.

14. Apley AG, Soloman L, Osteomyelitis. Appley's System of Orthopaedics and Fractures, 10th ed, British Government. Pp 27-48 2019.

15. Sabbatani S,Fiorino S, The treatment of wounds during World War I]. Le infezioni in medicina : rivista periodica di eziologia, epidemiologia, diagnostica, clinica e terapia delle patologie infettive, 2017 Jun 1 [PubMed PMID: 28603241] 
16. Lineaweaver W. Howard R, Soucy D, et al. Topical antimicrobial toxicity. Arch Surg. 1985;120(3):267270.

17. Kozol RA, Gillies C, Elgebaly SA. Effects of sodium hypochlorite (Dakin's solution) on cells of the wound module. Arch Surg. 1988;123(4):420-423.

18. Cooper ML, Laxer JA, Hansbrough JF. The cytotoxic effects of commonly used topical antimicrobial agents on human fibroblasts and keratinocytes. J Trauma. 1991;31(6):775-782; discussion 782-784.

19. Heggers J, Sazy J, Stenberg B, et al. Bactericidal and wound-healing properties of sodium hypochlorite solutions: the 1991 Lindberg Award. J Burn Care Rehabil. 1991;12(5):420-424.

20. Bolton LL, Oleniacz W, Constantine B, et al. Repair and antibacterial effects of topical antiseptic agents. In: Maibach H, Lowe N (eds). Models in Dermatology, Vol. 2. Basel, Switzerland: Karger;1985:145-158.

21. Wang L, Bassiri M, Najafi R, et al. Hypochlorous acid as a potential wound care agent. Part I. Stabilized Hypochlorous acid: A component of the inorganic armamentarium of innate immunity. $J$ Burns Wounds. 2007;6:e5.

22. Sakarya S, Gunay N, Karakulak M, Osturk B, Ertugrul B. Hypochlorous acid: an ideal wound care agent with powerful microbicidal, antibiofilm, and wound healing potency. WOUNDS. 2014;26(12):342-350.

23. Calhoun J. Biomolecular Infection. Book of Musculoskeletal Infection. Marcel Dekker. Texas, USA

24. Susanto, D., Sudrajat dan R. Ruga. 2012. Studi Kandungan Bahan Aktif Tumbuhan Meranti Merah (Shorea leprosula Miq) Sebagai Sumber Senyawa Antibakteri. Mulawarmnan Scientifie. 11 (2): 181-190.

25. Charan J dan Biswas T. How to Calculate Sample Size for Different Study Designs in Medical Research? Indian J Psychol Med. 121-126. 